\title{
\begin{tabular}{|l|l}
$\begin{array}{l}\text { Royal } \\
\text { Geographical } \\
\text { Society } \\
\text { with IBG }\end{array}$ \\
\hline $\begin{array}{l}\text { Advancing geography } \\
\text { and geographical learning }\end{array}$
\end{tabular}
}

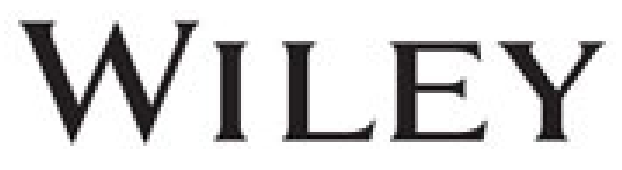

Notes on the Chobe River, South Central Africa

Author(s): Benjamin F. Bradshaw

Source: Proceedings of the Royal Geographical Society and Monthly Record of Geography,

New Monthly Series, Vol. 3, No. 4 (Apr., 1881), pp. 208-213

Published by: Wiley on behalf of The Royal Geographical Society (with the Institute of British

Geographers)

Stable URL: http://www.jstor.org/stable/1800745

Accessed: 17/06/2014 23:44

Your use of the JSTOR archive indicates your acceptance of the Terms \& Conditions of Use, available at

http://www.jstor.org/page/info/about/policies/terms.jsp

JSTOR is a not-for-profit service that helps scholars, researchers, and students discover, use, and build upon a wide range of content in a trusted digital archive. We use information technology and tools to increase productivity and facilitate new forms of scholarship. For more information about JSTOR, please contact support@jstor.org. 
from the sea. In this work he was thoroughly and worthily aided by Admiral Sir Henry Keppel. Any one who had seen what pirates did when they attacked a village, could have no sympathy with them or their actions. He believed that the success of Chinese colonisation in Saràwak would be imitated in other parts of Borneo. The work they had done for the benefit of the Dutch Government in Java was most remarkable, and they were quiet and orderly. As heathen they had vices peculiar to themselves, but still they were the best colonisers in Asia, and great results would follow the arrival of large numbers of them in Borneo. He would advise the gentlemen connected with the North Borneo Company to foster the immigration of Chinese into their territory. Labour contracts should not be entered into as in Cuba and Queensland, but they should be allowed to sell their labour in the best market. They would then work hard for the future prosperity of the colony.

The President, in proposing a vote of thanks to the author of the paper, said he had given them a great deal of information which had evidently been carefully and accurately collected. Englishmen were very apt to consider themselves the great colonisers of the world, and indeed they had done a work of which they might justly be proud. They had taken possession of and extended themselves over immense tracts of country, which were likely to perpetuate a race as vigorous and enterprising as our own; but there were certain climatic conditions which opposed their spreading in every region of the world. Although men like Sir James Brooke and Mr. Dent might lead the way in civilising districts at present inhabited by barbarous or semibarbarous people, it was quite clear that Borneo could never be settled by persons of English race; and as it seemed to be the fate of inferior races to give way to others more energetic, it was probable that the huge islands of the Eastern seas would in process of time be inhabited by descendants of the Chinese race. There was, however, one great feature of present times which could not be overlooked. Unfortunately it could not be said that wars had ceased, but they were now generally on a comparatively small scale, and the devastation caused by them was slight indeed when contrasted with that of the wars of past days. He believed that if an accurate census could have been taken in India at the time that England became possessed of it, and if another were taken at the present day, it would be found that the population had increased by upwards of 50,000,000. No doubt, as Asia became more and more under the domination of the three great empires, Russia, China, and Great Britain, the population would increase enormously, and in process of time would overflow to the south, just as in ancient times it overflowed to the west. The west was now too strongly occupied to permit of wholesale immigration. In all probability China, with its 400,000,000 inhabitants, was destined to find an outlet in the, magnificent islands to the south. The Chinese constitution was fitted to the climate which persons of the English race were unable to stand.

\section{Notes on the Chobe River, South Central Africa.}

\section{By Dr. Benjamin F. Bradshaw.}

Map, p. 256.

The accompanying map of the Chobe river is taken for about 40 miles up from its mouth, and drawn from memory, as I had no instruments with me, and went into that part of the country more with the intention of hunting and obtaining natural history specimens, than making geographical explorations; but having travelled more or less for the last six years either along the bank of the river or in a boat, its peculiar 
course naturally made a very great impression upon me, more especially as I have been living at nine different places along its course, for periods varying from two weeks to more than four months. The portions of the river not coloured I have not visited, but I think the supposed course marked to be about the correct one.

The course of the river, so far as I have shown, is as nearly as possible east and west; at the mouth, the river appears to be about 200 yards wide, and there is no perceptible current. On the south side the bank is about 12 feet high; for a mile and a half the opposite bank is clothed thickly with reeds, and hippopotami are often to be seen in the water.

The soil is more or less sandy, and a short distance from the bank on the south side you get a low ridge of heavy sand, as seen in the map, and coloured yellow. The grass is there very coarse and long. The shallow pan which $I$ have marked, varies much in extent, being ioften quite dry in October and November; a large sheet of water is formed by the annual inundation, about a mile square.

The river is bounded on the southern side by a high sandy ridge, clothed with forest, more or less thick; the ridge in some parts recedes a mile or more from the edge of the water, but in other parts it comes quite up to it. In many places along the ridge a quantity of rocks are observed jutting out, some having the appearance of sandstone, others looking quite vitrified.

The trading station is situated nearly opposite the town of Impalera, on a sandy rise, at the edge of a small flat, which is covered with thick patches of thorn-trees, and used to be formerly the haunt of buffaloes. The position of this place, in long. $25^{\circ} 19^{\prime} \mathrm{E}$. and lat. $17^{\circ} 49^{\prime} \mathrm{S}$. (as also the variation of compass $18^{\circ}$ westerly, and the height 3213 feet), I obtained from Major Serpa Pinto on the 6th October, 1878. I was at that time living there, and succeeded in prevailing upon the Kafirs to allow him to come through to this side, as he was very ill, and the natives wanted to keep him a prisoner, owing to a dispute about the rate of payment they were to receive for carrying his things from the Barotse valley. Several white men are buried here, among them a trader, named Hewitt, who is interred under a large thorn-tree, and whom we strongly suspected had been poisoned by the late king Sepopo, July 1876, at Sesheke, on the Zambesi. His body was sent down here for burial.

The most important thing at the station is the hot salt spring, the temperature of which I could not take, as my thermometer was broken, but at times I could scarcely bear my hand in it. The ground all around it is quite spongy, like a shaking bog, but on probing with a stick I found hard rock at from two to three feet depth. This spring is covered every year, when the river rises, for about three months, namely, from the end of December, through January and February, to

No. IV.-APRIL, 1881.] 
the beginning of March, when it subsides. The salt is crusted thickly on the ground, and on all the vegetation around. It is about $\frac{1}{8}$ inch in thickness, varying in size up to four inches square. I have used a great deal of the salt, and found it pure and strong. A quiet, shallow stream, about three feet wide, flows out of it to the river, and is full of small fish, which do not seem to be incommoded by the heat of the water.

The northern bank opposite is formed by the island of Impalera, the town of the same name being situated on a sandy rise, close to the river. It is occupied by Masubias, under a chief appointed by the Barotse nation, called Makumba, but is at present deserted, owing to a civil war having broken out between the Barotse on one side and the Masubias on the other, headed by Wana-Wena, the king elected on the death of Sepopo in October 1876, and deposed in May 1878, the Masubias being assisted by a tribe from the north-east called Ma-kupi-kupi, which tribe I am unacquainted with. The Masubias succeeded in burning down Sesheke, and taking the women and children as well as the cattle; but in the first engagement they were beaten with the loss of Ra Masokatan, a Masubia chief, whom I shall have occasion to mention again. The last news I had before leaving the Zambesi in May 1879 was that the Ma-kupi-kupis had sent for reinforcements, and the Masubias were flying up the Chobe river, intending to settle at Mababe, in Khame's country, the chief of the Bamangwato.

Two stony hills covered with bush lie to the right and left, and about 500 yards to the rear of the town. The left or western one has an immense baobab-tree growing on the top at the right-hand corner. During a heavy inundation the river rises about two feet in the houses, and the people are obliged to leave there for a time.

The river here is 400 yards wide. I have often fired across it with my rifle, and with the 400 yards sight my bullet struck the opposite side above the water-line. About two miles above the trading station are the rapids, the only ones known on this river, as far as I could hear from the natives; they are caused by a chain of rocks running in a northwesterly direction, approaching more to the north, are about 800 yards in length, and also form a rapid in the Zambesi. Some of the islands in the rapids are covered with a kind of sonorous sand, which gives most doleful shrieks when walked upon; the same thing may also be noticed on the Zambesi, near Sesheke. There are several small rocky hills on the south side of the river, near the rapids, the largest standing alone, as shown in the map.

The trees about here consist of seshuma and wild loquat, both fruittrees, various thorns, mopani, and along the river and in the islands willows and a species of scrubby yellow-wood. The country for about four miles along the river is very rocky, the sandy ridge gradually approaching the banks; it is covered with thick forest, tangled vines, scrubby bush, and long grass, and becomes the feeding-ground of 
numerous hippopotami at night. Under the ridge is to be seen one portion of the river coming from the north and another from the west, which latter evidently leaves the northern channel, forming an island as shown in the map. This island, as well as all the northern side of the river, as far as the rapids, is under water during the annual inundation. At that time the rivers Zambesi and Chobe are one, the whole country being one vast lake as far as the eye can reach, with here and there a tree or small island appearing above the waste of water; on the south side, the water at the same period comes up to the edge of the forest growing on the sandy ridge (marked yellow in the map). Opposite the marshes is a valley which, winding very much, extends for seven or eight miles in a southerly direction; it is covered with large kameel-thorn trees, and grass from four to eight feet in height. Near its upper end it contains a water hole, and about half a mile from the river there is a pan which is often the resort of wild-fowl. Along the edges, the bush is so thick as to be almost impassable, and a few years ago was the resort of elephants and buffaloes; the introduction of firearms among the natives has led to their being all driven out, and there are now only a few koodoos and pallahs remaining.

Proceeding up the river a couple of miles, the sandy ridge is found to approach close to the water, and is very abrupt and high, thickly clothed with vegetation; at the base, a row of wild date palms give it quite a tropical appearance. The two islands look very beautiful, being thickly grown with yellow-wood. The river soon turns to the northward, making a very large bend at least eight miles in length. The path here leaves the river and goes across a flat covered with long grass; the soil looks very fertile about here, and has been planted by the natives many years ago, until they were driven away to the north bank through fear of the Amandebele nation, who under Mosilikatze carried destruction through a great part of this country. Crossing the flat, Ra Masokatan's town, inhabited by Masubias, is to be seen on the opposite bank, a patch of high ground. The river here is very narrow and deep, not more than 70 yards wide; in the bank on the south side, which is very high and thickly covered with bush, are numerous fossils, as I was informed by a friend, but too late for me to see what they were before leaving the country. The sandy ridge here recedes from the river for a long distance, there being a flat above the level of the inundation, but covered with bush and several varieties of spike grass, and the resort of innumerable tsetse fly. Near the left-hand corner of Section No. 2 of my map may be seen a large lagoon, nearly surrounded with marsh, the haunt of numerous crocodiles; both sides of the river here are covered with water during the flood, and the whole country is like a lake. In Section No. 3 will be seen a large amount of swamp, and the river takes a very winding course, becoming narrow and deep, and bounded by quantities of reeds; it is one of the best parts of the country for wild-fowl from August to November. 
The river rises annually from 15 to 18 feet; commencing in January it is at its full height in March, and falls until January again; it is never turbid; it fills very gradually at first, but the decline is rapid, and goes on more slowly during the winter months. The rains commence in October or November (although I have known them one year, 1873, to begin on the 29th September), and generally end in March or April. The rest of the winter is fine, with perhaps one slight shower in June or July, very often none. The prevailing winds are from the east, except during the rains, which often come up from the west. Hail-storms are very rare; I only saw three during my stay in the country: on the 19th October, 1875 ; 12th November, 1877; and on the 29th April, 1879. The last did considerable harm to the natives along the river, who were going to Mababe, breaking their cooking vessels and calabashes; it also destroyed numbers of guinea-fowls and francolins. The temperature at my residence at Ma Chikory Camp (Section 3 of the map) during October and November, in the shade, was from $95^{\circ}$ to $110^{\circ}$.

The boats used on the river are hollowed out of the trunk of a tree, and are very good in calm water, but will not rise over waves. The fish are numerous, chiefly consisting of the silurus, a fish called Hydrocyon Forskalii (also found in the Nile), noted for its formidable row of teeth outside the lips; whistlers, with a long dorsal spine, supposed to poison if it wounds; three species of bream, and a kind of suckingfish; the four last are very good eating.

The Masubias are very black in colour of skin; physically they are well developed about the chest and arms, due to rowing, but they are very lazy, great thieves and bad servants. They manage their boats well, and are perfect adepts at spearing fish. The game found along the river, though now scarce, comprises elephants, hippopotami, buffaloes, lions, koodoos, pallahs, water-bucks, pokus, zebras, harris-bucks, and a small species of bush-buck, red with white spots. On the south bank and on the north leché antelopes are plentiful, also pokus and reedbucks.

The tsetse fly is found in great abundance on the south bank of the. river, and extends back from eight to twelve miles; it is not found on the north bank in the flats; it has no effect on game, but all tame animals are killed by it, with the exception of goats. Bushmen have told me that the fly breeds in buffalo dung, and it seems to be true, for when those animals are driven out the fly almost disappears, and if the small game also was exterminated it would probably disappear altogether. However, I do not think it matters much, as I consider it no country for a white population to settle in, consisting as it does of heavy belts of sand and rocky hills, and there are so few places where water can be had.

The drought in winter for seven or eight months is also another serious drawback, and the grass in winter is bad for cattle in most 
places; there is also a poison plant, called by the Bushmen machow, which springs up in September, October, and November, when the grass is burned, and is very fatal to cattle. The usual horse sickness peculiar to the country is also very bad here.

\section{A Journey along the Coasts of New Ireland and Neighbouring Islands.}

By the Rev. G. Brown.

New IreLAND, situated between lat. $2^{\circ} 25^{\prime}$ and $4^{\circ} 52^{\prime}$ S., and long. $153^{\circ} 12^{\prime}$ and $150^{\circ} 30^{\prime}$ E., has not been much visited by white men. Whalers often obtained a few supplies whilst coasting along, but not much was known of the places or the people, with the single exception of a small district at the south-east end in which are the harbours of Port Carteret, Port Sulphur, and Port Praslin, and where the French colony of the Marquis de Rays is at present formed.

In a former paper * I gave an account of the first journey across the island, at a point near Cape Rossel, N.N.E. of Port Hunter. At this place an elevation of nearly 3000 feet was obtained. From this place, going in a north-westerly direction, the range gradually decreases in height for about 25 miles, to a place called Kuramut, about 15 miles south-east from Cape Givry, when it again rises very abruptly, and trends away more to the westward. At this place, Kuramut, there seems, from seaward, to be a decided break in the land, as if the island had been at one time divided by a channel, and it was long thought that it was very much narrower there than is represented on the present charts. We often asked the natives about this, and they, no doubt thinking that we wished the island to be narrow there, made it narrower and narrower every time we asked about it; until finally, when I asked them if I could drag my boat across, they assured me that, with the exception of one rather difficult place, I could do so with very little trouble. I did not believe this, but still thought that it was comparatively narrow there, though I knew also that few, if any, of my informants had ever seen the place, as they were all from adjoining districts, and as a rule natives in these parts do not go much into other districts, as the fashion here is not simply to "heave 'arf a brick" at a stranger, but to kill and eat every one they catch.

On the 22nd of June, 1880, I called off Kuramut in our steam-launch, and arranged with the chiefs there to go as guides early the next morning. We then ran down the coast to pick up an anchorage, which we did outside a small island about five miles from Kuramut. Here we collected a few specimens of the coast formation to forward to Sydney

* 'Journal R. G. S.,' vol. xlvii. p. 137.-For general map, consult 'Proceedings,' new series, vol. iii. p. 128. 


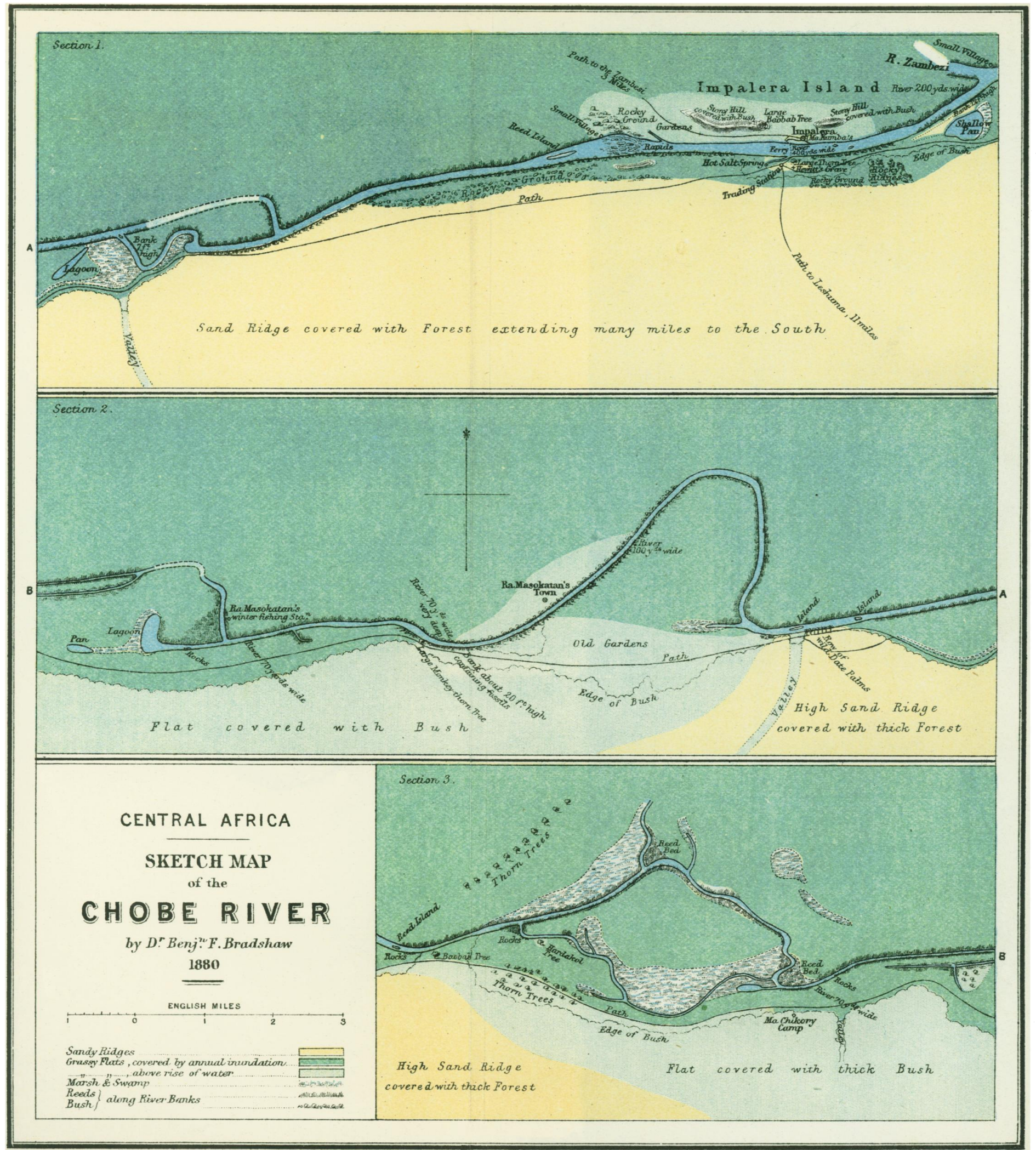

